\title{
Urgensi Peraturan Daerah Pengelolaan Daerah Aliran Sungai Bengawan Solo dalam Rangka Penguatan Fungsi Lingkungan Hidup dan Good Governance
}

\author{
I Gusti Ayu Ketut Rachmi Handayani \\ Fakultas Hukum UNS \\ Jl. Ir. Sutami No. 36 A Surakarta \\ ayu_igk@yahoo.com
}

\begin{abstract}
The damage of Drainage Basin (DAS) comes to be a factor on the unavoidable flooding disaster area. In Indonesia, most of Drainage Basins - particularly in Java including Bengawan Solo Drainage Basin have experienced damage. This research is to analyze the urgency of the local regulation on the management of Bengawan Solo Drainage Basin in order to strengthen the function of ecosystem and good government. The method used in this research is a judicial-empirical or non- doctrinal method. The result of the research concludes that in such condition in which the threat of the crisis of support capability on ecosystem and environment being faced by Indonesia is so real. Hence, legislation of legal norms on the management of Integrated Drainage Basin at Bengawan Solo is highly needed along with the intention to strengthen the democracy and constitutional state and management of Good Governance. On the other hand, in Central Government, there has been Government Regulation No. 37 Year 2012 about the Management of Drainage Basin and it is time to follow up in the form of Local Regulation.
\end{abstract}

Key words : Local regulation on management of drainage basin, function of environment, good governance.

\begin{abstract}
Abstrak
Rusaknya Daerah Aliran Sungai (DAS) adalah salah satu penyebab yang membuat suatu daerah tidak akan terbebas dari banjir. Kebanyakan Daerah Aliran Sungai di Indonesia terutama di Jawa termasuk DAS Bengawan Solo telah mengalami kerusakan. Penelitian ini mengkaji urgensi Peraturan Daerah Pengelolaan DAS Bengawan Solo dalam rangka penguatan fungsi lingkungan hidup dan good governance. Adapun metode yang digunakan dalam penelitian ini adalah yuridis empiris atau non doktrinal. Hasil penelitian menyimpulkan bahwa dalam kondisi saat ini, di mana ancaman krisis daya dukung ekosistem dan lingkungan hidup yang dihadapi Indonesia sangat nyata, maka legislasi norma hukum pengelolaan DAS Terpadu di DAS Bengawan Solo sangat diperlukan seiring dengan ikhtiar untuk memperkuat demokrasi dan negara hukum, serta tata kelola pemerintahan yang baik (good governance). Di sisi lain, di tingkat Pusat telah ada Peraturan Pemerintah No. 37 Tahun 2012 tentang Pengelolaan DAS dan sudah saatnya ditindaklanjuti dalam bentuk peraturan daerah.
\end{abstract}

Kata Kunci : Perda PDAS, fungsi lingkungan hidup, good governance 


\section{Pendahuluan}

Ketidakseimbangan antara manusia dan sumber-sumber alam, antara lain disebabkan oleh rusaknya sumber alam sebagai akibat dari aktivitas manusia, karena itu maka dilakukanlah pengelolaan Daerah Aliran Sungai (DAS). Hal seperti itu dapat terjadi karena keterbelakangan manusia terhadap pengetahuan lingkungan dan kehidupan ekonominya yang miskin sehingga mereka dihadapkan pada pilihan untuk memenuhi kebutuhan hidup. Berkembangnya tuntutan yang meluas agar kebijakan-kebijakan resmi negara yang pro-lingkungan dapat tercermin dalam bentuk perundang-undangan untuk ditaati oleh semua pemangku-kepentingan (stakeholders). Tidak terkecuali, Indonesia juga menghadapi tuntutan yang sama, yaitu perlunya disusun suatu kebijakan yang dapat dipaksakan berlakunya dalam bentuk undang-undang tersendiri yang mengatur mengenai lingkungan hidup. Manusia sering dianggap sebagai kendala atau bahkan sebagai perusak sumber daya alam. ${ }^{1}$ Bentuk kerusakan sumber daya alam oleh manusia disebabkan karena kurangnya kesadaran dan pengetahuan manusia ataupun karena tekanan kebutuhan ekonomi. Karena itu, faktor manusia perlu diperhitungkan secara baik, sehubungan dengan tujuan akhir dari pengelolaan DAS adalah untuk meningkatkan kesejahteraan serta kemakmuran bagi manusia yang hidup di dalam atau di luar DAS tersebut. ${ }^{2}$

Pembinaan aktivitas manusia dalam pemanfaatan sumber daya alam dalam rangka pengelolaan DAS dimaksudkan untuk membangkitkan dan meningkatkan kesadaran, kemauan dan kemampuan manusia agar dapat berperan serta secara aktif dalam pengelolaan sumber daya alam sehingga tercapai manfaat yang maksimal dan berkesinambungan. ${ }^{3}$ Keberhasilan konservasi DAS pada akhirnya ditentukan oleh pemakai dan pemilik lahan sendiri. Dalam hal ini diperlukan adanya motivasi agar para pemilik dan pemakai lahan merasa wajib, mau, dan mampu melaksanakan konservasi tanah dalam rangka pengelolaan DAS. ${ }^{4}$ Usaha konservasi DAS pada hakekatnya adalah bagian dari pengelolaan lingkungan hidup pada umumnya. Hal itu wajar sebab DAS merupakan salah satu bentuk dari lingkungan hidup. Bentuk

\footnotetext{
${ }^{1}$ Soekanto Reksohadiprodjo, Ekonomi Sumber Daya Alam dan Energi, BPFE, Yogyakarta, 1998, hlm. 53.

${ }^{2}$ G.M. Cunningham, “Total Catchment Management - Resource Management for the Future”, Journal of Soil Conservation, New South Wales 42(1), 1986, p. 4 - 5.

${ }^{3}$ Mitchell Bruce, B Setiawan, Dwita Hadi Rahmi, Pengelolaan Sumberdaya dan Lingkungan, Gadjah Mada University Press, Yogyakarta, 2000, hlm. 14.

${ }^{4}$ M. Nerbas, "An Environmental Audit of the Eastern Irrigation District", Brooks, Alberta, Canadian Water Resources Journal, 17(4),1992, p. 391 - 403.
} 
pengelolaan lingkungan hidup yang lain, misalnya pengelolaan perairan laut, usaha pertambangan dan industri, yang kesemuanya mempunyai tujuan yang sama, yaitu untuk kesejahteraan umat manusia baik generasi sekarang maupun mendatang. ${ }^{5}$

Menurut Sudarmanto, tujuan akhir konservasi DAS adalah terwujudnya kondisi yang optimal dari sumber daya vegetasi, tanah, sehingga mampu memberi manfaat secara maksimal dan berkesinambungan bagi kesejahteraan manusia. ${ }^{6}$ Dengan melihat tujuan konservasi DAS seperti tersebut di atas maka dalam konservasi DAS yang lebih dulu dihadapi adalah terbinanya kesadaran dan kemampuan masyarakat untuk menggunakan dan memelihara sumber daya alam tersebut secara bijaksana. Meskipun, kesadaran masyarakat akan lingkungan hidup bukan merupakan sasaran langsung, tetapi ini merupakan keadaan awal yang harus diciptakan demi tercapainya tujuan akhir tersebut.

Dalam upaya untuk lebih meningkatkan hasil dari konservasi DAS, perlu diletakkan secara mantap dasar-dasar atau prinsip-prinsip yang dianut dalam pengelolaannya dengan maksud untuk menjaga konsistensinya terutama pada daerah kabupaten atau kota. Dasar-dasar dalam konservasi DAS diwujudkan dalam upaya-upaya pokok untuk mencapai tujuan akhir dari pengelolaan DAS seperti tersebut di atas. Dengan melihat tujuan serta akibat dari konservasi DAS, maka menurut Lee, pengelolaan DAS meliputi 4 upaya pokok, yaitu: a) pengelolaan lahan melalui usaha konservasi dalam arti yang luas; b) pengelolaan air melalui pengembangan sumber air; c) pengelolaan vegetasi, khususnya pengelolaan hutan yang memiliki fungsi perlindungan terhadap tanah dan air; d) pembinaan kesadaran dan kemampuan manusia dalam menggunakan sumber daya alam secara bijaksana melalui usaha penerangan dan penyuluhan.

\section{Rumusan Masalah}

Adapun rumusan masalah dalam penelitian ini, yaitu apa urgensi Perda Pengelolaan DAS Bengawan Solo dalam rangka penguatan fungsi lingkungan hidup dan good governance?

${ }^{5}$ Martin S., "Partnerships for Local Environmental Action: Observations on the First Two Years of Rural Action for the Environment", Journal of Environmental Planning and Management, 38(2), 1995, p. 149-65.

${ }^{6}$ Sudarmanto, Teknik Konservasi Tanah dalam Rangka Pengelolaan Daerah Aliran Sungai, Sub Balai Rehabilitasi Lahan dan Konservasi Tanah Wonogiri, Jateng, 1992, hlm. 12. 


\section{Tujuan Penelitian}

Tujuan penelitian ini adalah untuk mengetahui dan menganalisis urgensi Perda Pengelolaan DAS Bengawan Solo diperlukan dalam rangka penguatan fungsi lingkungan hidup dan good governance.

\section{Metode Penelitian}

Dalam penelitian ini digunakan metode yuridis empiris atau non doktrinal, yang dimaksudkan sebagai usaha mendekati masalah yang diteliti dengan sifat hukum yang sesuai dengan kenyataan yang hidup dalam masyarakat. Pendekatan yang digunakan bersifat sosiologis/empiris menggunakan pendekatan non positivistik dan menggunakan analisis bersifat kualitatif. ${ }^{7}$ Adapun sifat penelitiannya deskriptif developmental yang memberikan gambaran secara sistematis terhadap obyek yang akan diteliti, selanjutnya disusun model yang dapat dikembangkan untuk mengatasi permasalahan di lapangan. Pendekatan penelitian menggunakan pendekatan penelitian kualitatif. Dengan mengutip pendapat dari Denzin dan Lincoln menjelaskan bahwa penelitian kualitatif adalah penelitian yang menggunakan latar alamiah, dengan maksud menafsirkan fenomena yang terjadi dan dilakukan dengan jalan melibatkan berbagai metode yang ada. ${ }^{8}$

Lokasi penelitian meliputi DAS Bengawan Solo. Lokasi tersebut diambil dengan pertimbangan di daerah tersebut sangat dinamis dan merupakan DAS Prioritas I. Dalam penelitian ini data yang diperlukan meliputi data primer maupun data sekunder. Data Primer, yaitu data yang diperoleh dari sumber data langsung atau tangan pertama, terutama yang menyangkut aspek perilaku, persepsi, sikap, dan motivasi eksekutif dan legislatif dalam penyusunan Perda. Data Sekunder, yaitu data yang bukan diusahakan sendiri pengumpulannya oleh peneliti. Data sekunder dapat berupa majalah, laporan, hasil penelitian terdahulu, peraturan perundangundangan serta publikasi lainnya. Sumber data sekunder meliputi bahan hukum primer, sekunder dan tersier.

Instrumen pengumpul data terbagi menjadi dua yakni untuk data primer menggunakan wawancara dan kuesioner. Wawancara ini dilakukan dengan indeepht

\footnotetext{
${ }^{7}$ Peter Mahmud Marzuki, Penelitian Hukum, Kencana Prenada Media Group, Jakarta, 2006, hlm. 26.

${ }^{8}$ Lexy J. Moleong, Metodologi Penelitian Kualitatif, Remaja Rosdakarya, Bandung, 2005, hlm. 5.
} 
interview, yaitu metode pengumpulan data melalui wawancara yang dilakukan secara mendalam kepada sumber data. ${ }^{9}$ Untuk memberikan penajaman dan elaborasi data lebih lanjut dilakukan Focus Group Discussion (FGD) dengan melibatkan pihak-pihak pemangku kepentingan. Adapun untuk data sekunder menggunakan identifikasi isi dengan metode studi kepustakaan, dimana metode ini digunakan dalam rangka memperoleh data sekunder, yaitu mengumpulkan data berupa buku-buku ilmiah yang berhubungan dengan masalah yang diteliti, dokumen-dokumen, peraturan perundangan yang sesuai dan lain sebagainya dengan membaca dan mengkajinya.

Dalam penelitian ini penulis menggunakan teknik analisis kualitatif, mengingat data yang terkumpul sebagian besar merupakan data kualitatif. Teknik ini tepat bagi penelitian yang menghasilkan data yang bersifat kualitatif, yaitu data yang tidak bisa dikategorikan secara statistik kualitatif.

\section{Hasil Penelitian dan Pembahasan}

\section{Pengelolaan Daerah Aliran Sungai}

Pengelolaan DAS biasanya mengacu pada pengelolaan dua anasirnya (component) yang dianggap terpenting, yaitu sumberdaya tanah dan air. Adapun anasir yang lain, seperti iklim, vegetasi, relief dan manusia, diperlukan sebagai faktor-faktor dalam pengelolaan. Maksud pengelolaan DAS ialah mendapatkan manfaat lengkap yang sebaik-baiknya dari DAS sesuai dengan kemampuannya, untuk memenuhi kebutuhan masyarakat yang beraneka ragam dan yang berkembang menurut waktu. Dalam ungkapan "sesuai dengan kemampuannya" tersirat pengertian selaras dan lestari. Ungkapan "manfaat lengkap" dan "kebutuhan masyarakat yang beraneka ragam dan yang berkembang menurut waktu" mengisyaratkan bahwa (1) hasil keluaran DAS tidak boleh hanya bermacam tunggal, akan tetapi harus terdiri atas berbagai hasil keluaran yang berkombinasi secara optimum, dan (2) rencana pengelolaan harus bersifat lentur (flexible) yang berisi sejumlah alternatif.

Untuk mengarahkan pengelolaan, diperlukan tiga unsur pengarah, yaitu: pertama, variable-variabel keputusan (decision variables), yang menjadi sumber pembuatan alternatif. Kedua, maksud dan tujuan (objectives). Ketiga, kendala (constraint), yang

\footnotetext{
${ }^{9}$ W. Gulo, Metodologi Penelitian, Gramedia Widiasarana Indonesia, Jakarta, 2002, hlm. 119.
} 
membatasi gerak variabel-variabel keputusan dalam membuat alternatif-alternatif untuk mencapai maksud dan tujuan yang ditetapkan. Khusus mengenai pengelolaan DAS, yang dapat dipakai sebagai variabel-variabel keputusan, ialah: (1) keempat dasar untuk pengelolaan DAS yang telah disebutkan terdahulu (DAS selaku penghubung dua waduk air alam utama, kehadiran DAS didukung oleh kegiatan pertukaran bahan dan energi, DAS berkembang melalui proses perubahan dalam dan DAS bergatra ganda yang dapat dimanfaatkan untuk berbagai peruntukan), (2) pemanfaatan DAS harus dapat menimbulkan pemerataan manfaat antara daerah hulu dan hilir, dan (3) pengembangan DAS harus dapat memberikan sumbangan bagi kepentingan regional dan atau nasional, seperti maksud atau tujuan pengelolaan DAS telah disebutkan di atas.

Adapun yang menjadi kendala terhadap perkembangan DAS ialah iklim, relief, tanah, air, sumberdaya mineral, vegetasi, beberapa gatra tertentu manusia, ruang/ luas, bentuk, ketercapaian dan keterlindasan. Pendek kata semua anasir DAS dikenai atau terlibat dalam pengelolaan. Dalam rencana pengelolaannya, DAS dibagi menjadi dua satuan pengelolaan, yaitu: pertama, satuan pengelolaan hulu mencakup seluruh daerah tadah atau daerah kepala sungai. Kedua, satuan pengelolaan hilir mencakup seluruh daerah penyaluran air atau daerah bawahan. Istilah "watershed" digunakan secara terbatas untuk menamai daerah tadah, sedang daerah bawahan dikenal dengan istilah "commanded area". Yang dinamakan "commended area" ialah daerahdaerah yang secara potensial berpengairan. Di DAS yang dapat dibangun suatu bendungan atau waduk maka seluruh daerah yang terkuasai oleh bangunan tersebut (daerah yang terletak dibawah garis tinggi pintu bendungan atau waduk) merupakan "commended area". Pengelolaan daerah tadah ditujukan untuk mencapai hal-hal berikut ini: (1) pengendalian aliran permukaan tanah (excess) yang merusak, sebagai usaha mengendalikan banjir, (2) memperlancar infiltrasi air kedalam tanah. (3) mengusahakan pemanfaatan aliran permukaan untuk maksud-maksud yang berguna, (4) mengusahakan semua sumberdaya tanah dan air untuk memaksimumkan produksi. Faktor-faktor yang berdaya (affect) atas program pengelolaan daerah tadahan atau DAS hulu ialah: (1) bentuk dan luas daerah tadahan, (2) lereng dan timbulan makro (3) keadaan tanah, termasuk fisiografi dan hidrologi tanah, (4) intensitas, jangka waktu dan tagihan curah hujan, (5) rupa dan mutu vegetasi penutup, dan (6) penggunaan lahan terkini. 
Adapun tujuan pengelolaan DAS hilir dapat diringkas sebagai berikut: (1) mencegah atau mengendalikan banjir dan sedimentasi yang merugikan, sehingga tidak merusak dan menurunkan kemampuan lahan.(2) memperbaiki pengatusan (drainage) lahan untuk meningkatkan kemampuannya. (3) meningkatkan dayaguna air dari sumber-sumber air tersediakan. (4) meliorasi tanah, termasuk memperbaiki daya tanggap tanah terhadap pengairan, dan kalau perlu juga reklamasi tanah atas tanah-tanah garaman, alkali, sulfat masam, gambut tebal, dan mineral mentah. Faktorfaktor pokok yang berdaya atas program pengelolaan daerah hilir ialah: (1) bentuk daerah hilir dan perbandingan luasnya dengan luas daerah tadahan; (2) perbedaan landaian (gradient) lereng umum daerah hilir terhadap landaian lereng umum daerah tadahan; (3) timbulan makro, ketinggian muka lahan pukul rata, jeluk (depth) pukul rata air tanah, dan keadaan tanah; (4) intensitas, jangka waktu dan agihan curah hujan; (5) rupa dan vegetasi penutup; (6) penggunaan lahan kini. ${ }^{10}$

Perlakuan terhadap DAS hulu merupakan bagian terpenting dari keseluruhan pengelolaan DAS, karena hal itu akan menentukan keuntungan yang dapat diperoleh, atau kesempatan yang terbuka, dalam pengelolaan DAS hilir. Pengelolaan DAS hilir menentukan seberapa besar keuntungan yang secara potensial dapat

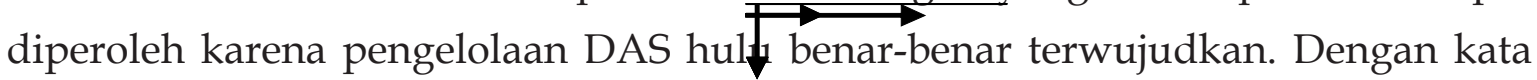
lain, pengelolaan DAS hilir bertujuan meningkatkan daya tanggapnya terhadap dampak pengelolaan DAS hulu. Hubungan ini dapat digambarkan dalam skema sebagai berikut:

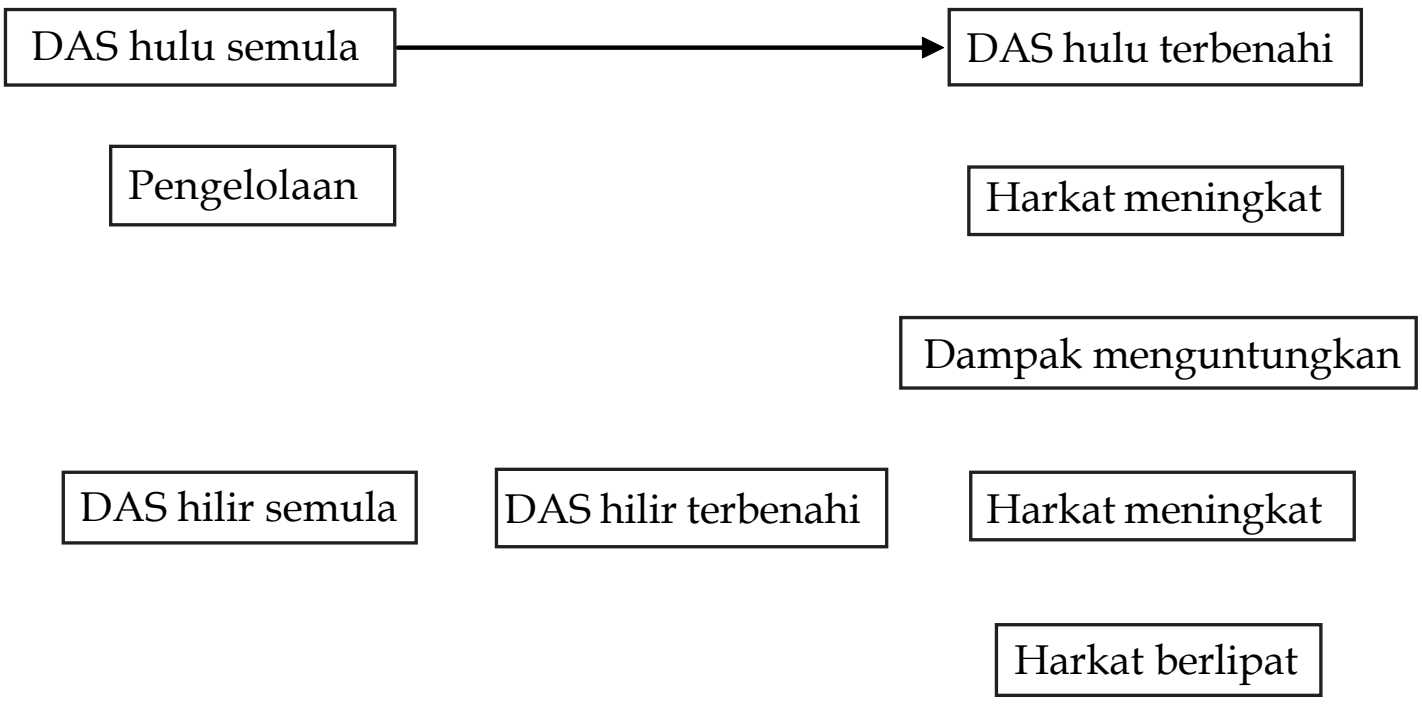

${ }^{10}$ K Ray, \& D.R. Arora, Technology of Agricultural Land Development and Water Management, Satya Pakashan, Tech. India Publ, New Delhi, 1973, p.13. 
Dari bagian ini tampak, bahwa pengelolaan DAS hulu bertujuan rangkap: (1) meningkatkan harkatnya sebagai lahan usaha dan atau lahan permukiman; (2) memperbaiki dampaknya atas DAS hilir untuk memperluas peluang memperbaiki keadaan DAS hilir. Pengelolaan DAS hilir berperanan melipatkan pengaruh perbaikan yang telah dicapai di DAS hulu. Menurut pandangan ekologi maka daerah hulu dikelola sebagai daerah penyumbang (donor) bahan dan energi, atau boleh juga disebut sebagai lingkungan pengendali (conditioning environtment). Sementara itu, daerah hilir merupakan daerah penerima (acceptor) bahan dan energi, atau lingkungan konsumsi atau lingkungan yang dikendalikan (commanded environment). Dengan demikian, pengelolaan DAS harus bersifat menyeluruh dan dapat memadukan bagian hulu dan hilir menjadi satu sistem.

\section{Prinsip-Prinsip Good Governance}

Dari perspektif sistem administrasi pembangunan, akar persoalan kehancuran lingkungan terletak pada kegagalan bekerjanya natural resources and environmental governance system untuk mendorong proses-proses pertukaran ekologis secara efektif, efisien dan berkeadilan antara dua ruang yang berbeda namun saling terikat sesamanya. Ruang tersebut adalah "ruang human system"dan "ruang bagi non-human system" di kawasan DAS. Kegagalan tata- pemerintahan lingkungan tampak pada adanya inkonsistensi regulasi antar daerah dalam menata kawasan DAS. Otoritas administratif masing-masing daerah yang berada dalam kawasan DAS gagal menghasilkan kebijakan lingkungan yang sinergis secara lintas sistem administrasi lokal (trans-local environmental policy implementation). Bilamana kegagalan demi kegagalan berlangsung terus-menerus, maka pada akhirnya terjadilah krisis ekologi yang akarnya terletak pada kegagalan keseluruhan sistem tata-pemerintahan lingkungan (environmental governance failure). ${ }^{11}$

Kekacauan sistem tata-pengelolaan dan regulasi pemanfaatan sumberdaya alam dan lingkungan di "ruang sosial" selanjutnya akan mendorong krisis pada "ruang sistem ekologi" DAS, dimana ekosistem makin terkooptasi dan menerima beban yang sangat berat akibat kesalahan atau ketidakselarasan dalam kebijakan politik dan pengambilan keputusan yang dilakukan oleh sistem administrasi. Kenyataan inilah yang memunculkan tesis bahwa ecological crisis is an environmental governance

${ }^{11}$ Arya Hadi Darmawan, Sistem Tata-Pemerintahan Sumberdaya Alam dan Lingkungan di Daerah Aliran Sungai Citanduy: Perspektif Politik Ekologi, 2004, hlm. 11. 
crisis. ${ }^{12}$ Jika persoalan governance muncul selaras dengan kegagalan sistem desentralisme (OTDA) yang telah mengarah pada penguatan "sentralisasi otoritas lokal", maka segera terpikirkan salah satu solusinya yaitu memperbaharui semangat desentralisasi agar re-sentralisasi tata-pengelolaan sumberdaya alam dan lingkungan di tingkat daerah/kabupaten atau kota tidak berlanjut makin kronis. Pembaharuan tata-kelembagaan dan tata-pemerintahan lingkungan dipandang penting dilakukan, meski selama ini perspektif ekologi manusia klasikal mempercayai bahwa sistem ekologi (alam) memiliki kemampuan adaptasi untuk menstabilkan setiap guncangan dan ketidakstabilan, serta kehancuran ekosistem yang dialaminya tanpa campur tangan manusia. Oleh karena itu, intervensi segera pada tataran makro sistem sosioekologi DAS menjadi sangat penting untuk diwujudkan. Pandangan ini didasarkan pada pemikiran, bahwa upaya perbaikan lingkungan yang mengandalkan "tanpa rekayasa kelembagaan dan tata-pemerintahan" akan sulit membantu proses regenerasi dan stabilisasi sistem ekologi DAS secara cepat. Terlebih bila idenya adalah mengembalikan status ekologis ekosistem DAS. Dari pertimbangan tersebut, maka upaya memikiran kembali untuk memperbaharui sistem tata-pemerintahan sumberdaya alam dan lingkungan di kawasan DAS menjadi sangat relevan dan mendesak untuk diwujudkan melalui regulasi di tingkat daerah (Perda Pengelolaan DAS). Produk hukum yang baik merupakan salah satu syarat dari pelaksanaan Good Governance di daerah.

Secara konseptual dapat dipahami bahwa good governance menunjukkan suatu proses yang memposisikan rakyat dapat mengatur ekonominya. ${ }^{13}$ Institusi serta sumber sosial dan politiknya tidak hanya sekedar dipergunakan untuk pembangunan, tetapi juga untuk menciptakan integrasi bagi kesejahteraan rakyat. Good governance juga dipahami sebagai suatu penyelenggaraan manajemen pemerintahan yang solid dan bertanggung jawab yang sejalan dengan prinsip demokrasi dan pasar, pemerintahan yang efisien, serta pemerintahan yang bebas dan bersih dari kegiatan korupsi, kolusi, dan nepotisme (KKN). ${ }^{14}$

Berkaitan dengan good governance, Miftah Thoha berpendapat, sebagai tata pemerintahan yang terbuka, bersih, berwibawa, transparan dan bertanggung

${ }^{12}$ Ibid., hlm. 12

${ }^{13}$ Dedi Mulyadi, Pelayanan Publik dalam Konsep Good Governance, 2012, hlm. 2.

${ }^{14}$ A. Ubaedillah dan Abdul Razak, Pendidikan Kewarganegaraan (Civic Education): Demokrasi HAM dan Masyarakat Madani, Edisi Ketiga, diterbitkan kerjasama ICCE UIN Syarif Hidayatullah Jakarta dan Prenada Media Group, Jakarta, 2010, hlm. 159. 
jawab. ${ }^{15}$ Selanjutnya menurut pendapat Bank Dunia dalam laporannya mengenai 'Good Governance and Development' tahun 1992, mengatakan bahwa 'good governance' sebagai pelayanan publik yang efisien, sistem pengadilan yang dapat diandalkan, pemerintahan yang bertanggung jawab (accountable) pada publiknya. Sementara itu pengertian good governance menurut Anggito Abimanyu yang disitir oleh Mahfud $\mathrm{MD}$, bahwa 'good governance is "participatory, transparent and accountable, effective and equitable. And it promotes the rule of low" dan "good governance will never credible as long as governance conditionalitiy is imposed on a country without consulting civil society". ${ }^{16}$

Philipus M. Hadjon dkk, dalam peradilan administrasi di Nederland dikenal nomenkelatur asas-asas umum pemerintahan yang baik (ABBB) yang merupakan norma-norma hukum tidak tertulis, yang senantiasa harus ditaati oleh pemerintah atau dengan bahasa lain ABBB adalah asas-asas hukum tidak tertulis, dimana untuk keadaan-keadaan tertentu dapat ditarik aturan-aturan hukum yang dapat diterapkan. meliputi : 1. asas persamaan, asas bahwa hal-hal yang sama harus diperlakukan sama, dipandang sebagai salah satu asas hukum yang paling mendasar dan berakar didalam kesadaran hukum, khusus mengenai pemahaman kebijaksanaan ialah menunjukan perwujudan asas perlakuan yang sama atau asas persamaan; 2 . asas kepercayaan, asas kepercayaan termasuk di dalam asas-asas hukum yang paling mendasar dalam hukum publik dan hukum perdata, dalam hukum administrasi dianut sebagai asas bahwa harapan-harapan yang ditimbulkan sedapat mungkin harus dipenuhi. Asas ini sebagai dasar yuridis dari janji-janji, keterangan-keterangan, aturan-aturan kebijakasanan dan bentuk-bentuk rencana (yang tidak diatur dengan perundang-undangan); ${ }^{17}$ 3. asas kepastian hukum, asas yang memiliki dua aspek, yang satu lebih bersifat hukum material, yang lain bersifat formil. Aspek hukum materil berhubungan erat pada asas kepercayaan, asas kepastian hukum menghalangi badan pemerintah untuk menarik kembali suatu ketetapan atau mengubahnya untuk kerugian yang berkepentingan; 4. asas kecermatan, asas ini mengadung arti bahwa suatu keputusan harus dipersiapkan dan diambil dengan cermat. Atau dapat diartikan sebagai suatu keputusan harus mengandung arti, bahwa suatu keputusan harus dipersiapkan dan diambil dengan cermat; 5. asas hlm. 1-2.

${ }^{15}$ Miftah Thoha, Birokerasi Pemerintahan Indonesia di Era Reformasi, Kencana Prenada Madia Group, Jakarta, 2008,

${ }^{16}$ Nomensen Sinamo, Hukum Administrasi Negara Suatu Kajian Kritis Tentang Birokrasi Negara, Jala Permata Aksara, Jakarta, 2010, hlm. 141.

${ }^{17}$ Surachmin, Asas dan Prinsip Hukum Serta Penyelenggaraan Negara, Edisi Ketiga, Yayasan Gema Yustisia Indonesia, Jakarta, 2010, hlm. 40. 
pemberian alasan (motivasi), adalah suatu keputusan harus dapat didukung oleh alasan-alasan yang dijadikan dasarnya; 6. larangan 'detournement de pouvoir' (penyalahgunaan wewenang), adalah suatu wewenang tidak boleh digunakan untuk tujuan lain selain untuk tujuan yang diberikan; 7. larangan bertindak sewenangwenang. ${ }^{18}$

Menurut UNDP, good governance adalah suatu hubungan sinergi antara negara, sektor swasta (pasar), dan masyarakat yang berlandaskan pada sembilan karakteristik, yakni: partisipasi, rule of law, transparansi, sikap responsif, berorientasi konsensus, kesejahteraan/kebersamaan, efektif dan efisien, akuntabilitas, dan visi strategis. ${ }^{19}$

Sedangkan menurut Jazim Hamidi, pengertian Asas-asas Umum Pemerintahan yang Layak (AAUPL) atau good governance adalah : 1. AAUPL merupakan nilai-nilai etik yang hidup dan berkembang dalam lingkungan hukum administrasi negara; 2 . AAUPL berfungsi sebagai pegangan bagi pejabat administrasi negara dalam menjalankan fungsinya yang terkait dengan beschikking; 3. sebagian besar dari AAUPL masih merupakan asas-asas yang tidak tertulis, abstrak dan dapat digali dalam praktek kehidupan di masyarakat; 4. sebagaian AAUPL sudah menjadi kaidah tertulis dan terpecah dalam berbagai peraturan hukum positif. ${ }^{20}$

\section{Teori Bekerjanya Hukum}

Sistem hukum tidak hanya mengacu pada aturan (codes of rules) dan peraturan (regulations), namun mencakup bidang yang luas, meliputi struktur, lembaga dan proses (procedure) yang mengisinya serta terkait dengan hukum yang hidup dalam masyarakat (living law) dan budaya hukum (legal structure). Menurut Lawrence Friedman, unsurunsur sistem hukum itu terdiri dari struktur hukum (legal structure), substansi hukum (legal substance) dan budaya hukum (legal culture). ${ }^{21}$ Struktur hukum meliputi badan eksekutif, legislatif dan yudikatif serta lembaga-lembaga terkait, seperti Kejaksaan, Kepolisian, Pengadilan, Komisi Judisial, Komisi Pemberantasan Korupsi (KPK) dan lain-lain. Sedangkan substansi hukum adalah mengenai norma, peraturan maupun

\footnotetext{
${ }^{18}$ Philipus M. Hadjon dkk, Pengantar Hukum Administrasi Indonesia (Intoduction to the Indonesian Administrative Law), Gajah Mada University Press, Yogyakarta, 1999, hlm. 270.

${ }^{19}$ United Nations Development Programme, UNDP and Governance for Sustainable Human Development (NewYork), 2002.

20 S.F. Marbun, Dimensi-Dimensi Hukum Administrasi Negara, UII Press, Yogyakarta, 2001, hlm 210-211.

${ }^{21}$ Lawrence Friedman, American Law, W.W. Norton \& Company, London, 1984, hlm. 6.
} 
undang-undang. Budaya hukum adalah meliputi pandangan, kebiasaan maupun perilaku dari masyarakat mengenai pemikiran nilai-nilai dan pengharapan dari sistem hukum yang berlaku. Dengan perkataan lain, budaya hukum itu adalah iklim dari pemikiran sosial tentang bagaimana hukum itu diaplikasikan, dilanggar atau dilaksanakan. Tanpa budaya hukum sistem hukum itu sendiri tidak akan berdaya, seperti ikan mati yang terkapar di keranjang, bukan seperti ikan hidup yang berenang di lautnya (without legal culture, the legal system is inert, a dead fish lying in a basket, not a living fish swimming in its sea). ${ }^{22}$

Setiap masyarakat, negara dan komunitas mempunyai budaya hukum. Selalu ada sikap dan pendapat mengenai hukum. Hal ini tidak berarti bahwa setiap orang dalam satu komunitas memberikan pemikiran yang sama. Banyak sub budaya dari suku-suku yang ada, agama, kaya, miskin, penjahat dan polisi mempunyai budaya yang berbeda antara satu dengan yang lainnya. Yang paling menonjol adalah budaya hukum dari orang dalam, yaitu hakim dan penasehat hukum yang bekerja di dalam sistem hukum itu sendiri, karena sikap mereka membentuk banyak keragaman dalam sistem hukum. Setidak-tidaknya kesan ini akan mempengaruhi penegakan hukum dalam masyarakat. Hukum adalah kontrol sosial dari pemerintah (law is governmental social control), sebagai aturan dan proses sosial yang mencoba mendorong perilaku, baik yang berguna atau mencegah perilaku yang buruk. ${ }^{23} \mathrm{Di}$ sisi lain kontrol sosial adalah jaringan atau aturan dan proses yang menyeluruh yang membawa akibat hukum terhadap perilaku tertentu, misalnya aturan umum perbuatan melawan hukum. ${ }^{24}$ Tidak ada cara lain untuk memahami sistem hukum selain melihat perilaku hukum yang dipengaruhi oleh aturan keputusan pemerintah atau undang-undang yang dikeluarkan oleh pejabat yang berwenang.

Jika seseorang berperilaku secara khusus adalah karena diperintahkan hukum atau karena tindakan pemerintah atau pejabat lainnya atau dalam sistem hukum. Tetapi kita juga membutuhkan kontrol sosial terhadap pemerintah, karena tidak dapat kita pungkiri, bahwa tiada kuda tanpa kekang. Begitu juga tiada penguasa dan aparaturnya yang bebas dari kontrol sosial. Semua tahu ada orang yang berwenang menyalahgunakan jabatannya, praktek suap dan KKN sering terjadi dalam tirani birokrat. Maka untuk memperbaiki harus ada kontrol yang dibangun

\footnotetext{
22 Ibid., hlm. 7.

${ }^{23}$ Donald Black, Behavior of Law, Academic Press, New York, San Fransisco, London, 1976, hlm. 2.

${ }^{24}$ Lawrence Friedman, American Law,..., Op.Cit, hlm. 3.
} 
dalam sistem. Dengan kata lain, hukum mempunyai tugas jauh mengawasi penguasa itu sendiri, kontrol yang dilakukan terhadap pengontrol. Pemikiran ini berada di balik pengawasan dan keseimbangan (check and balance) dan di balik Peradilan Tata Usaha Negara, Inspektur Jenderal, Auditur dan lembaga-lembaga seperti, KPK, Komisi Judisial. Kesemuanya ini harus mempunyai komitmen yang tinggi untuk memberantas segala bentuk penyalahgunaan wewenang dari pihak penguasa.

Hukum akan menjadi berarti apabila perilaku manusia dipengaruhi oleh hukum dan apabila masyarakat menggunakan hukum menuruti perilakunya, sedangkan di lain pihak efektivitas hukum berkaitan erat dengan masalah kepatuhan hukum sebagai norma. Hal ini berbeda dengan kebijakan dasar yang relatif netral dan bergantung pada nilai universal dari tujuan dan alasan pembentukan undangundang. Dalam praktek kita melihat ada undang-undang/Perda sebagian besar dipatuhi dan ada undang-undang/Perda yang tidak dipatuhi. Sistem hukum jelas akan runtuh jika setiap orang tidak mematuhi undang-undang dan undang-undang itu akan kehilangan maknanya. Ketidakefektifan undang-undang cenderung mempengaruhi waktu sikap dan kuantitas ketidakpatuhan serta mempunyai efek nyata terhadap perilaku hukum, termasuk perilaku pelanggar hukum. Kondisi ini akan mempengaruhi penegakan hukum yang menjamin kepastian dan keadilan dalam masyarakat.Kepastian hukum dapat kita lihat dari dua sudut, yaitu kepastian dalam hukum itu sendiri dan kepastian karena hukum. "Kepastian dalam hukum" dimaksudkan bahwa setiap norma hukum itu harus dapat dirumuskan dengan kalimat-kalimat di dalamnya tidak mengandung penafsiran yang berbeda-beda. Akibatnya akan membawa perilaku patuh atau tidak patuh terhadap hukum.

Dalam praktek banyak timbul peristiwa-peristiwa hukum, di mana ketika dihadapkan dengan substansi norma hukum yang mengaturnya, kadangkala tidak jelas atau kurang sempurna sehingga timbul penafsiran yang berbeda-beda yang akibatnya akan membawa kepada ketidakpastian hukum. Sedangkan "kepastian karena hukum" dimaksudkan, bahwa karena hukum itu sendirilah adanya kepastian, misalnya hukum menentukan adanya lembaga daluarsa, dengan lewat waktu seseorang akan mendapatkan hak atau kehilangan hak. Berarti hukum dapat menjamin adanya kepastian bagi seseorang dengan lembaga daluarsa akan mendapatkan sesuatu hak tertentu atau akan kehilangan sesuatu hak tertentu.Hukum tidak identik dengan undang-undang, jika hukum diidentikkan dengan perundang-undangan, maka salah satu akibatnya dapat dirasakan, adalah kalau ada bidang kehidupan yang belum 
diatur dalam perundang-undangan, maka dikatakan hukum tertinggal oleh perkembangan masyarakat. Demikian juga kepastian hukum tidak identik dengan dengan kepastian undang-undang.

Apabila kepastian hukum diidentikkan dengan kepastian undang-undang, maka dalam proses penegakan hukum dilakukan tanpa memperhatikan kenyataan hukum (Werkelijkheid) yang berlaku.Para penegak hukum yang hanya bertitik tolak dari substansi norma hukum formil yang ada dalam undang-undang (law in book's), akan cenderung mencederai rasa keadilan masyarakat. Seyogyanya penekanannya di sini, harus juga bertitik tolak pada hukum yang hidup (living law). Lebih jauh para penegak hukum harus memperhatikan budaya hukum (legal culture), untuk memahami sikap, kepercayaan, nilai dan harapan serta pemikiran masyarakat terhadap hukum dalam sistim hukum yang berlaku. Penegakan hukum pada prinsipnya harus dapat memberi manfaat atau berdaya guna (utility) bagi masyarakat, namun di samping itu masyarakat juga mengharapkan adanya penegakan hukum untuk mencapai suatu keadilan. Biarpun demikian, tidak dapat kita pungkiri, bahwa apa yang dianggap berguna (secara sosiologis) belum tentu adil, begitu juga sebaliknya apa yang dirasakan adil (secara filosofis), belum tentu berguna bagi masyarakat.

Dalam kondisi yang demikian ini, masyarakat hanya menginginkan adanya suatu kepastian hukum, yaitu adanya suatu peraturan yang dapat mengisi kekosongan hukum tanpa menghiraukan apakah hukum itu adil atau tidak. Kenyataan sosial seperti ini memaksa pemerintah untuk segera membuat peraturan secara praktis dan pragmatis, mendahulukan bidang-bidang yang paling mendesak sesuai dengan tuntutan masyarakat tanpa perkiraan strategis, sehingga melahirkan peraturanperaturan yang bersifat tambal sulam yang daya lakunya tidak bertahan lama. Akibatnya kurang menjamin kepastian hukum dan rasa keadilan dalam masyarakat. Substansi undang-undang dan atau peraturan daerah sebaiknya disusun secara taat asas, harmoni, dan sinkron dengan nilai-nilai yang terkandung dalam Pancasila dan Undang-Undang Dasar 1945. Untuk itu harus dilakukan dengan mengabstraksikan nilai-nilai yang terkandung dalam Pancasila dan Undang-Undang Dasar 1945 kemudian menderivasi, yakni menurunkan sejumlah asas-asas untuk dijadikan landasan pembentukan undang-undang. Semua peraturan-peraturan hukum yang dikeluarkan secara sektoral oleh kementerian-kementerian dan pemerintah provinsi, kabupaten/kota yang bersangkutan harus serasi dan sinkron dengan ketentuan undang-undang. 
Perlu dimaklumi bahwa banyak peraturan undang-undang atau peraturan daerah sering tidak berpijak pada dasar moral yang dikukuhi rakyat, bahkan sering bertentangan. Pada taraf dan situasi seperti ini, kesadaran moral warga masyarakat tentu saja tidak akan lagi selalu sama dan sebangun dengan kesadaran hukum rakyat. Hukum yang dikembangkan dari cita pembaharuan dan pembangunan negara-negara nasional pun karenanya akan memerlukan dasar legitimasi lain, yang tak selamanya dipungut begitu saja dari legitimasi moral rakyat yang telah ada selama ini. Hukumhukum ekonomi, lalu lintas dan tata kota yang mendasarkan diri maksud-maksud pragmatis jelaslah kalau terlepas dari kesadaran moral tradisional. ${ }^{25}$

\section{Instrumen Perlindungan dan Pengelolaan Fungsi Lingkungan DAS}

Pasal 5 UUPLH mengamanatkan agar pelaksanaan pengelolaan lingkungan hidup dilakukan melalui inventarisasi lingkungan hidup, penetapan wilayah ekoregion dan penyusunan Rencana Perlindungan dan Pengelolaan Lingkungan Hidup (RPPLH). Pengelolaan DAS yang terpadu idealnya juga sesuai dengan RPPLH. RPPLH terdiri atas RPPLH nasional, RPPLH provinsi, RPPLH Kabupaten/ Kota. ${ }^{26}$ RPPLH nasional dibuat oleh menteri Lingkungan Hidup berdasarkan inventarisasi nasional, RPPLH provinsi dibuat berdasarkan RPPLH nasional, inventarisasi tingkat pulau/kepulauan dan inventarisasi tingkat ekoregion, RPPLH tingkat kabupaten/kota dibuat berdasarkan RPPLH provinsi, inventarisasi tingkat pulau/kepulauan dan inventarisasi tingkat ekoregion. ${ }^{27}$

Penyusunan RPPLH memperhatikan aspek-aspek berikut: a) keanekaragaman karakter dan fungsi ekologis, b) sebaran penduduk, c) sebaran potensi sumber daya alam, d) kearifan lokal e) aspirasi masyarakat dan f) perubahan iklim. RPPLH memuat rencana tentang aspek-aspek berikut: a) pemanfaatan dan / atau pencadangan sumber daya alam, b) pemeliharaan dan perlindungan kualitas dan / atau fungsi lingkungan hidup, c) pengendalian, pemantauan, serta pendayagunaan dan pelestarian sumber daya alam, dan d) adaptasi dan mitigasi perubahan iklim. RPPLH menjadi dasar penyusunan dan dimuat dalam rencana pembangunan jangka panjang dan rencana pembangunan jangka menengah. ${ }^{28}$

${ }^{25}$ Soetandyo Wignjosoebroto, Hukum, Paradigma, Metode dan Dinamika Masalabnya, Cetakan Pertama, ELSAM dan HUMA, Jakarta, 2002, hlm. 380.

${ }^{26}$ Pasal 9 ayat (1) UU No. 32 Tahun 2009

${ }^{27}$ Pasal 9 ayat (4) UU No. 32 Tahun 2009

${ }^{28}$ Pasal 10 UU No. 32 Tahun 2009 
Kajian Lingkungan Hidup Strategis (KLHS) sebagaimana dirumuskan dalam Pasal 1 butir 10 UUPPLH adalah rangkaian analisis sistematis, menyeluruh dan partisipatif untuk memastikan bahwa prinsip pembangunan berkelanjutan telah menjadi dasar dan terintegrasi dalam pembangunan suatu wilayah dan/atau kebijakan, rencana dan/atau program. Pengelolaan DAS Terpadu idealnya berdasarkan pada KLHS. "KLHS merupakan instrumen yang tidak dikenal dalam UULH 1997 dan UULH 1982, sehingga ia dapat dikatakan sebagai instrumen baru dalam pengelolaan lingkungan hidup. Diberlakukannya KLHS membuktikan bahwa instrumen-instrumen yang sebelumnya ada tidak mampu mencegah dan mengatasi timbulnya masalah-masalah lingkungan hidup. Instrumen-instrumen yang ada sebelum KLHS pada pokoknya berorientasi kegiatan individual, misalkan Amdal dan izin, sedangkan masalah-masalah lingkungan dapat timbul karena kebijakan makro pemerintah atau program-program pemerintah yang tidak sejalan dengan konsep pembangunan berkelanjutan.

Pengaturan KLHS dalam UUPLH terdapat dalam 4 pasal, yaitu Pasal 15, 16, 17 dan 18. Pasal 15 UUPLH mewajibkan "pemerintah dan pemerintah daerah untuk membuat KLHS guna memastikan bahwa pembangunan berkelanjutan telah menjadi dasar dan terintegrasi dalam pembangunan satu wilayah dan/atau kebijakan atau program". KLHS merupakan dokumen kebijakan yang antara lain memuat: a) kapasitas daya dukung dan daya tampung lingkungan hidup untuk pembangunan; b) perkiraan mengenai dampak dan risiko lingkungan hidup; c) kinerja layanan/jasa ekosistem; d) efisiensi pemanfaatan sumber daya alam; e) tingkat kerentanan dan kapasitas adaptasi terhadap perubahan iklim; f) tingkat ketahanan dan potensi keanekaragaman hayati.

Pemerintah dan pemerintah daerah wajib melaksanakan KLHS ke dalam penyusunan atau evaluasi: ${ }^{29}$ a) Rencana Tata Ruang Wilayah (RTRW) beserta rencana rincinya Rencana Pembangunan Jangka Panjang (RPJP) dan Rencana Pembangunan Jangka Menengah (RPJM) nasional, provinsi dan kabupaten/kota; b) Kebijakan, rencana dan/atau program yang berpotensi menimbulkan dampak dan/atau risiko lingkungan hidup. Berbeda dari instrumen-instrumen lainnya, misalkan izin Amdal dan audit, lingkungan yang diwajibkan atas pelaku usaha atau kegiatan, KLHS diwajibkan atas pemerintah sendiri. Pemerintah maupun pemerintah daerah dalam melaksanakan KLHS wajib melibatkan masyarakat dan pemangku kepentingan

\footnotetext{
${ }^{29}$ Pasal 15 ayat (2) UU No. 32 Tahun 2009
} 
lainnya. KLHS dilaksanakan dengan mekanisme sebagai berikut: ${ }^{30}$ a) pengkajian daya dukung dan daya tampung lingkungan hidup untuk pembangunan; $b$ ) perumusan alternatif penyempurnaan kebijakan rencana dan/atau program; c) rekomendasi perbaikan untuk pengambilan keputusan kebijakan, rencana, dan/ atau program yang mengintegrasikan prinsip pembangunan berkelanjutan. Hasil KLHS menjadi dasar bagi kebijakan, rencana atau program pembangunan suatu wilayah. Jika hasil KLHS menyatakan bahwa daya dukung dan daya tampung sudah terlampaui, langkah-langkah yang dilakukan adalah: a) kebijakan, rencana atau program pembangunan tersebut wajib diperbaiki sesuai dengan rekomendasi KLHS; b) segala usaha atau kegiatan yang telah melampaui daya dukungan dan daya tampung lingkungan hidup tidak diperbolehkan lagi. Instrumen lain yang juga diperlukan dalam pengelolaan fungsi lingkungan adalah Baku mutu lingkungan hidup dan kriteria baku kerusakan lingkungan hidup. Baku mutu lingkungan hidup adalah instrumen untuk mengukur terjadinya pencemaran lingkungan. ${ }^{31}$ Baku mutu lingkungan terdiri atas :32 a) Baku mutu air; b) Baku mutu air limbah; c) Baku mutu air laut; d) Baku mutu udara ambien; e) Baku mutu emisi; f) Baku mutu gangguan; g) Baku mutu lain sesuai dengan perkembangan ilmu dan teknologi.

Kriteria baku kerusakan lingkungan hidup sebagaimana dirumuskan dalam Pasal 1 butir 15 adalah "ukuran batas perubahan sifat fisik, kimia dan/atau hayati lingkungan hidup yang dapat ditenggang oleh lingkungan hidup untuk dapat tetap melestarikannya. Kriteria baku kerusakan lingkungan hidup merupakan instrumen untuk menentukan terjadinya kerusakan lingkungan hidup. Kriteria baku kerusakan lingkungan hidup meliputi kriteria baku kerusakan ekosistem dan kriteria baku kerusakan akibat perubahan iklim. Kriteria baku kerusakan ekosistem meliputi: ${ }^{33}$ a) kriteria baku kerusakan tanah untuk produksi biomassa; b) kriteria baku kerusakan terumbu karang; c) kriteria baku kerusakan lingkungan hidup yang berkaitan dengan kebakaran hutan dan/atau lahan; d) kriteria baku kerusakan mangrove; e) kriteria baku kerusakan padang lamun; f) kriteria baku kerusakan gambut; g) kriteria baku kerusakan karst; h) kriteria baku kerusakan ekosistem lain sesuai perkembangan ilmu dan teknologi.

\footnotetext{
${ }^{30}$ Pasal 15 ayat (3) UU No. 32 tahun 2009

${ }^{31}$ Pasal 1 butir 13 UU No. 32 Tahun 2009

32 Pasal 20 ayat (2) UU No. 32 Tahun 2009

${ }^{33}$ Pasal 21 ayat (3) UU No. 32 Tahun 2009
} 
Kriteria baku kerusakan akbiat perubahan iklim didasarkan pada parameter, antara lain : (a) kenaikan temperatur, (b) kenaikan muka air laut, (c) badai, (d) kekeringan.

Instrumen yang juga penting adalah Analisis Mengenai Dampak Lingkungan. Amdal merupakan suatu upaya atau pendekatan untuk mengkaji apakah kegiatan pemanfaatan atau pengolahan sumber daya alam termasuk DAS atau kebijakan pemerintah akan dan dapat menimbulkan dampak terhadap lingkungan hidup.

Berdasarkan Pasal 25 UUPPLH dokumen Amdal memuat hal-hal berikut : (a) pengkajian dampak rencana usaha dan/atau kegiatan, (b) evaluasi kegiatan di sekitar lokasi rencana usaha dan/atau kegiatan, (c) saran masukkan serta tanggapan masyarakat terhadap rencana usaha dan/atau kegiatan (d) prakiraan terhadap besaran dampak serta sifat penting dampak yang terjadi jika rencana usaha dan/ atau kegiatan tersebut dilaksanakan, (e) evaluasi secara holistik terhadap dampak yang terjadi untuk menentukan kelayakan atau ketidaklayakan lingkungan hidup, (f) rencana pengelolaan dan pemantauan lingkungan hidup. Penyusunan dokumen Amdal dilakukan oleh pemrakarsa kegiatan dengan melibatkan masyarakat yang terkena dampak, pemerhati lingkungan atau masyarakat yang terpengaruh atas segala bentuk keputusan dalam proses Amdal. Pemrakarsa yang menyusun dokumen Amdal wajib memiliki sertifikasi kompetensi penyusunan Amdal yang diterbitkan oleh lembaga sertifikasi kompetensi penyusunan yang ditetapkan oleh Menteri Lingkungan Hidup.

\section{Permasalahan Perlindungan dan Pengelolaan DAS Bengawan Solo}

Daerah Aliran Sungai (DAS) Bengawan Solo merupakan DAS terbesar di Pulau Jawa, terletak di Propinsi Jawa Tengah dan Jawa Timur dengan luas wilayah 1.594.716,22 Ha. Lokasi DAS Bengawan Solo pada posisi 110¹8` BT sampai 112o45‘ BT dan 6o49'LS sampai 8o08` LS. DAS Bengawan Solo dibagi ke dalam tiga SubDAS, yang meliputi; SubDAS Bengawan Solo Hulu, Sub DAS Kali Madiun dan Sub DAS Bengawan Solo Hilir. ${ }^{34}$ Luas Sub DAS Bengawan Solo Hulu $\pm 6.072 \mathrm{~km} 2$, luas Sub DAS Kali Madiun $\pm 3.755 \mathrm{~km}^{2}$, sedangkan luas Sub DAS Bengawan Solo Hilir \pm $6.273 \mathrm{~km}^{2}$. SubDAS Bengawan Solo Hulu dan Kali Madiun mengalirkan air dari lereng gunung berbentuk kerucut yakni Gunung Merapi $( \pm 2.914 \mathrm{~m})$, Gunung Merbabu $( \pm 3.142 \mathrm{~m})$ dan Gunung Lawu $( \pm 3.265 \mathrm{~m})$. Secara administratif DAS

\footnotetext{
${ }^{34}$ Kabupaten Wonogiri dalam angka Tahun 2012
} 
Bengawan Solo mencakup 17 (tujuh belas) kabupaten dan 3 (tiga) kota, yaitu: Kabupaten: Boyolali, Klaten, Sukoharjo, Wonogiri, Karanganyar, Sragen, Blora, Rembang, Ponorogo, Madiun, Magetan, Ngawi, Bojonegoro, Tuban, Lamongan, Gresik dan Pacitan. Kota: Surakarta, Madiun dan Surabaya. ${ }^{35}$

Ada 20 Kabupaten/Kota yang berada di wilayah DAS Bengawan Solo. Dari seluruh kabupaten atau kota yang berada di DAS Solo tersebut, wilayah Kabupaten Bojonegoro merupakan wilayah yang terluas, sedangkan Kota Madiun merupakan wilayah terkecil, yang daerahnya masuk di dalam batas wilayah DAS Bengawan Solo. DAS Bengawan Solo berada dalam daerah yang beriklim tropis dengan suhu udara, kelembaban dan curah hujan yang cukup tinggi dan relatif seragam selama musim hujan. DAS Bengawan Solo memiliki dua musim, yaitu musim kemarau (Mei sampai Oktober) dan musim hujan (November sampai April), dengan kelembaban rata-rata $80 \%$, suhu bulanan rata-rata $26,7^{\circ} \mathrm{C}$. Suhu minimum $26,1^{\circ} \mathrm{C}$ terjadi pada bulan Juli, sedangkan suhu maksimum $27,2^{\circ} \mathrm{C}$ terjadi pada bulan oktober, lama penyinaran rata-rata bulanan 6,3 jam.

Kelembaban rata-rata bulanan pada DAS Bengawan Solo adalah sekitar $80 \%$, di mana kelembaban rata-rata bulanan minimum terjadi pada bulan September sebesar $77,4 \%$ dan kelembaban rata-rata bulanan maksimum terjadi pada bulan januari dan pebruari sebesar 82,3\%. DAS Bengawan Solo merupakan sebuah sumber air yang potensial bagi usaha-usaha pengelolaan dan pengembangan sumber daya air (SDA), untuk memenuhi berbagai keperluan dan kebutuhan, antara lain untuk kebutuhan domestik, air baku air minum dan industri, irigasi dan lain-lain. Pada saat musim kemarau, DAS Bengawan Solo sering mengalami kekeringan dan masalah intrusi air laut, sebaliknya pada musim hujan di beberapa kabupaten sering mengalami bencana banjir yang mengakibatkan kerugian harta benda dan jiwa manusia yang tidak sedikit.

Kondisi geomorfologi di DAS Bengawan Solo dibagi menjadi 6 (enam) zona yang terletak memanjang dari Timur-Barat, sejajar dengan garis pantai pulau Jawa yang secara berselang membentuk zona tertekan dan zona terangkat akibat aktivitas tektonik. Penggunaan lahan di DAS Bengawan Solo hampir seluruhnya merupakan kawasan budidaya, didominasi pada pemanfaatan sebagai lahan sawah, yakni sebesar 534.794,72 Ha atau sekitar 33\% dari seluruh luas wilayah DAS. Pemanfatan lahan besar lainnya adalah penggunaan lahan untuk tegalan/ladang, sebesar

${ }^{35}$ Kabupaten Wonogiri dalam angka Tahun 2012 
297.247,59 ha atau sekitar 18\% dari luas total DAS. Sedangkan penggunaan lahan yang bersifat memberikan perlindungan relatif sangat kecil. Proporsi penggunaan lahan yang kurang berimbang antara fungsi lindung dan fungsi budidaya, merupakan alasan logis sebab terjadinya berbagai masalah yang dihadapi DAS Bengawan Solo. Masalah banjir saat musim penghujan dan masalah kekeringan di musim kemarau adalah masalah utama yang selalu terjadi setiap tahun. Potensi Air di DAS Bengawan Solo dapat dibedakan menjadi dua, yaitu potensi air permukaan dan potensi airtanah. Potensi ketersediaan air permukaan DAS Bengawan Solo sangat besar sejumlah 16.003,50 juta $\mathrm{m}^{3}$ /tahun sementara untuk airtanah sebesar 2.943,50 juta $\mathrm{m}^{3}$ / tahun, namun keseluruhan potensi ketersediaan belum termanfaatkan secara optimal.

Perkiraan jumlah Penduduk di DAS Solo tahun 2012 kurang lebih ada 16.394.053 jiwa, dengan luas DAS sebesar 1.594.716,22 Ha, maka kepadatan penduduk di DAS Solo adalah 10,28 Jiwa/Ha atau sekitar 1.028 Jiwa/ Km². Berbagai masalah lingkungan telah terjadi di DAS Solo. Masalah-masalah tersebut antara lain; banjir, lahan kritis, pencemaran air, erosi (sedimentasi) dan permasalahan sosial lainnya.

Pertama, banjir. Banjir besar di DAS Bengawan Solo Hulu pernah terjadi pada 1966. Puncak banjir diperkirakan sebesar $4.000 \mathrm{~m}^{3} /$ det di Wonogiri, $2.000 \mathrm{~m}^{3} /$ det di Surakarta dan $1.850 \mathrm{~m}^{3}$ / det di Ngawi. Luas daerah genangan banjir di sebelah hulu Kota Surakarta sekitar 18.000 ha dan di Sragen sekitar 10.000 ha. Hampir seluruh daerah Surakarta tergenang banjir termasuk daerah perkotaan. Tinggi genangan yang terjadi di Kota Surakarta mencapai 1 sampai 2 m dan korban meninggal sebanyak 90 orang. Mengingat bahwa setiap tahun selalu ada kejadian banjir, terutama pada daerah-daerah rawan banjir, maka untuk mengatasi hal tersebut, pemerintah telah banyak membangun fasilitas pengendali banjir. Fasilitas pengendalian banjir yang terutama dalam Wilayah DAS Bengawan Solo adalah Bendungan Serbaguna Wonogiri (Waduk Gajah Mungkur) yang terletak sekitar $55 \mathrm{~km}$ disebelah hulu Kota Surakarta. Bendungan tersebut selesai dibangun pada tahun 1982 yang berfungsi sebagai pengendalian banjir mencakup daerah seluas $1.350 \mathrm{Ha}$. Waduk tersebut mempunyai kapasitas tampungan sebesar 220 juta $\mathrm{m}^{3}$ untuk mereduksi puncak banjir sebesar $4.000 \mathrm{~m}^{3} /$ det menjadi $400 \mathrm{~m}^{3}$ / det. Fasilitas lain yang berfungsi untuk mengurangi kerusakan akibat banjir adalah Flood Forecasting and Warning System (FFDAS). FFDAS yang berada di Bendungan Wonogiri adalah satu-satunya yang ada dalam wilayah studi. Sistem tersebut telah dipasang pada 1982 sebagai peralatan tambahan bendungan untuk memantau dan 
memperkirakan banjir yang masuk ke dalam waduk dan memberikan peringatan dini di daerah di sebelah hilir.

Kedua, erosi dan sedimentasi. Erosi lahan terutama terjadi di wilayah hulu DAS yaitu SubDAS Bengawan Solo Hulu dan SubDAS Madiun. Selanjutnya erosi akan mengakibatkan sedimentasi di daerah bawahnya hingga ke muara Sungai Bengawan Solo di Selat Madura.

Ketiga, lahan kritis. Berdasarkan hasil penelitian yang dilakukan oleh Balai Pengelolaan DAS Bengawan Solo (2010) disebutkan bahwa lahan yang terkategori sangat kiritis mencapai luas 770,21 ha dan lahan yang terkategori kritis mencapai luas $48.056,47$ ha.

Keempat, pencemaran. Selain menghadapi persoalan kerusakan lingkungan, DAS Bengawan Solo juga mengalami pencemaran air sungai-sungainya. Pencemaran lingkungan yang terjadi di Sungai Bengawan Solo disebabkan oleh limbah industri maupun limbah domestik. Adanya pencemaran oleh limbah cair ini telah mengakibatkan penurunan kualitas air sungai. Kualitas air terus menurun dari tahun ke tahun, hal ini tergambar dari hasil pengukuran beban pencemaran untuk BOD, COD dan NH3-N yang dilakukan dalam Prokasih Jawa Tengah.

\section{Urgensi Peraturan Daerah Pengelolaan DAS}

Berdasarkan uraian di atas, maka sudah saatnya dilakukan formulasi produk hukum di tingkat daerah dalam bentuk Perda dalam rangka pengelolaan DAS Bengawan Solo untuk mewujudkan good governance. Mengacu pada Teori Lawrence Friedman, bahwa bekerjanya hukum dipengaruhi tiga faktor, yaitu stuktur, substansi dan kultur. Pertama, struktur. Dalam hal struktur sudah ada lembaga baik di tingkat pusat maupun daerah yang menangani pengelolaan DAS, yaitu Kementerian Kehutanan, Kementerian PU, Kementerian Lingkungan dan instansi terkait di tingkat pusat. Di tingkat daerah ada Dinas Kehutanan, Badan Lingkungan Hidup, Bappeda dan instansi terkait lainnya baik provinsi maupun kabupaten. Kedua, substansi. Pada sisi substansi terdapat kelemahan, walaupun di tingkat pusat sudah ada UU Sumber Daya Air, UU Kehutanan, UU Perlindungan dan Pengelolaan Lingkungan Hidup namun di tingkat daerah belum ada produk hukum daerah yang mengatur pengelolaan DAS secara khusus dalam bentuk Perda. Selain permasalahan di atas, saat ini sudah ada PP No. 37 Tahun 2012 tentang Pengelolaan Daerah Aliran Sungai yang perlu ditindaklanjuti dengan sebuah Perda di tingkat daerah. 
Dalam rangka pengelolaan dan perlindungan DAS menuju good governance sudah saatnya pengelolaan DAS Terpadu sejalan dengan instrumen lingkungan hidup yang teriri dari RPPLH, KLHS, Baku Mutu Lingkungan Hidup, Baku Mutu Kerusakan dan AMDAL. Ketiga, Kultur. Dalam pengelolaan DAS faktor yang ketiga ini juga berperan sangat penting terutama dalam hal budaya sadar lingkungan dan mengelola DAS secara lestari dan berkelanjutan.

\section{Penutup}

Dari uraian di atas dapat disimpulkan bahwa Perda Pengelolaan DAS Bengawan Solo sudah saatnya dibentuk dan urgen dalam rangka penguatan fungsi lingkungan hidup dan good governance, mengingat permasalahan yang kompleks serta payung hukum pengelolaan DAS di tingkat daerah belum tersedia, khususnya Perda Pengelolaan DAS Bengawan Solo. Dalam rangka pengelolaan DAS Terpadu maka perlu diterbitkan Perda Pengelolaan DAS Bengawan Solo dalam rangka penguatan fungsi lingkungan hidup dan terwujudnya good governance.

\section{Daftar Pustaka}

A.Ubaedillah dan Abdul Razak, Pendidikan Kewarganegaraan (Civic Education): Demokrasi HAM dan Masyarakat Madani, Edisi Ketiga, diterbitkan kerjasama ICCE UIN Syarif Hidayatullah Jakarta dan Prenada Media Group, Jakarta, 2010.

Black,Donald, "Behavior of Law", Academic Press, New York, San Fransisco, London, 1976.

Cunningham, G M., Total Catchment Management - Resource Management for the Future, Journal of Soil Conservation, New South Wales 42(1). 1986.

Friedman, Lawrence, “American Law”, W.W. Norton \& Company, London, 1984.

Hadi Darmawan, Arya, Sistem Tata-Pemerintahan Sumberdaya Alam dan Lingkungan di Daerah Aliran Sungai Citanduy: Perspektif Politik Ekologi, 2004.

Kabupaten Wonogiri dalam Angka Tahun 2012.

Mulyadi, Dedi, Pelayanan Publik dalam Konsep Good Governance, 2012.

Moleong, Lexy J., Metodologi Penelitian Kualitatif, P.T. Remaja Rosdakarya, Bandung, 2005.

Mahmud Marzuki, Peter, Penelitian Hukum, Kencana Prenada Media Group, Jakarta, 2006. 
Martin S,. Partnerships for Local Environmental Action: Observations on the First Two Years of Rural Action for the Environment. Journal of Environmental Planning and Management 38 (2). 1995.

Marbun, S.F., Dimensi-Dimensi Hukum Administrasi Negara, UII Press, Yogyakarta, 2001.

Mitchell, Bruce., B Setiawan, Dwita Hadi Rahmi, Pengelolaan Sumberdaya dan Lingkungan, Gadjah Mada University Press, Yogyakarta, 2000.

M. Hadjon, Philipus, dkk, Pengantar Hukum Administrasi Indonesia (intoduction to the Indonesian Administrative Law), Gajah Mada University Press, Yogyakarta, 1999.

Nerbas, M., An Environmental Audit of the Eastern Irrigation District, Brooks, Alberta, 1991. Canadian Water Resources Journal 17(4), 1992.

Sinamo, Nomensen, Hukum Administrasi Negara Suatu Kajian Keritis Tentang Birokrasi Negara, Jala Permata Aksara, Jakarta, 2010.

Ray, K. \& Arora, D.R. Technology of Agricultural Land Development and Water Management. Satya Pakashan, Tech. India Publ, New Delhi, 1973.

Reksohadiprodjo, Soekanto, Ekonomi Sumber Daya Alam dan Energi, BPFE, Yogyakarta, 1998.

Sudarmanto, Teknik Konservasi Tanah dalam Rangka Pengelolaan Daerah Aliran Sungai. Sub Balai Rehabilitasi Lahan dan Konservasi Tanah Wonogiri, Jateng, 1992.

Surachmin, Asas dan Prinsip Hukum Serta Penyelenggaraan Negara, Edisi Ketiga 2, Yayasan Gema Yustisia Indonesia, Jakarta, 2010.

Thoha, Miftah, Birokrasi Pemerintahan Indonesia di Era Reformasi, Kencana Prenada Madia Group, Jakarta, 2008.

Wignjosoebroto, Soetandyo, "Hukum, Paradigma, Metode dan Dinamika Masalahnya", Cetakan Pertama, ELSAM dan HUMA, Jakarta, 2002.

W. Gulo, Metodologi Penelitian, Gramedia Widiasarana Indonesia, Jakarta, 2002.

United Nations Development Programme, UNDP and Governance for Sustainable Human Development (NewYork), 2002.

UU No. 32 Tahun 2009 tentang Perlindungan dan Pengelolaan Lingkungan Hidup PP No. 37 Tahun 2012 tentang Pengelolaan Daerah Aliran Sungai 